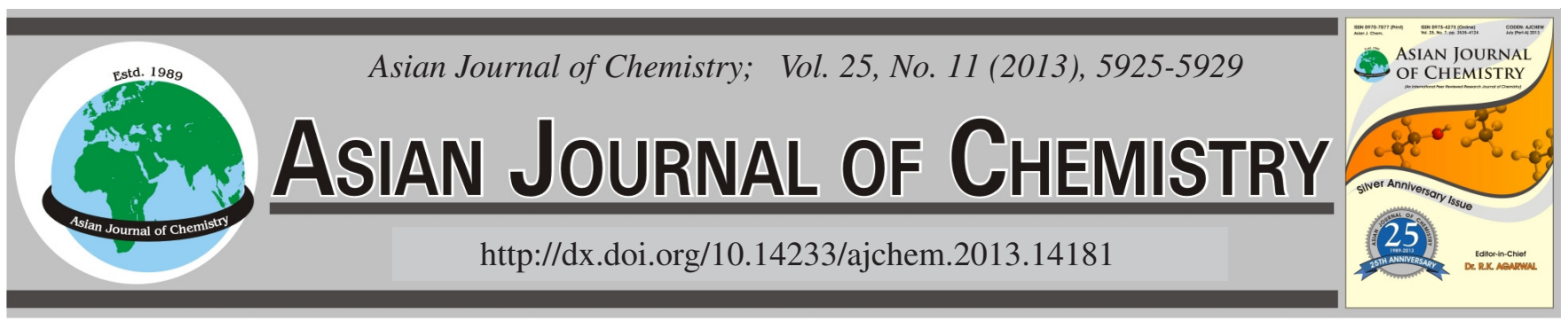

\title{
Study of Interaction of Mercuric Chloride with Bovine Serum Albumin by Multi-Spectroscopic Method
}

\author{
F. SHEN, Y.-M. He and Y. ZhоU*
}

College of Chemical Engineering and Materials Science, Zhejiang University of Technology, Hangzhou, P.R. China

*Corresponding author: Fax: +86 571 88320961; Tel: +86 13185079980; E-mail: zhouying@zjut.edu.cn

(Received: 7 June 2012;

Accepted: 18 April 2013)

AJC-13369

\begin{abstract}
The interaction of mercuric chloride with bovine serum albumins was investigated under the simulative physiological conditions. The fluorescence spectra in combination with UV absorption and circular dichroism spectra were used in the present work. A strong fluorescence quenching reaction of mercuric chloride towards bovine serum albumin was observed and the quenching mechanism was regarded as static quenching procedure. The association constant $(\mathrm{K})$ at different temperatures as well as thermodynamic parameters $e . g$., enthalpy change $(\Delta \mathrm{H})$, entropy change $(\Delta \mathrm{S})$ and Gibb's free energy $(\Delta \mathrm{G})$, were calculated. The results showed that the hydrophobic force plays an important role in the interaction of mercuric chloride to bovine serum albumin. In addition, the result of synchronous fluorescence showed that binding site of mercuric chloride is nearer to tryptophan than that of the tyrosine residue, alteration of secondary structure of bovine serum albumin in the presence of mercuric chloride was evaluated using the data obtained from UV and circular dichroism spectroscopies.
\end{abstract}

Key Words: Bovine serum albumin, Mercuric chloride, Interaction.

\section{INTRODUCTION}

Mercuric chloride is also named corrosive sublimate, which is soluble in water and highly potent poison. The ingestion of as little as $1 \mathrm{~g}$ can be fatal ${ }^{1,2}$. Human acute poisoning by mercuric mercury can cause headache, fever, stomatitis, corrosive gastroenteritis, etc. Kidneys are the main site of toxicity. Many reports have indicated that mercury(II) many cause diseases in animals and humans, especially about the immune disease ${ }^{3}$. Mercury(II) can through microbial methylation transform into methyl-mercury which has stronger toxicity and through the food chain accumulation and amplification. Thus it causes severe damage to the humans and animals which are on the top of the food chain ${ }^{4}$.

Serum albumin is the most abundant protein in blood plasma, accounting for $52-60 \%$ of the total plasmatic protein content. Albumin plays an important role in transporting endogenous ligands and xenobiotics mostly through the formation of non-covalent complexes at specific binding sites, actuating in the regulation of their plasmatic concentration ${ }^{5,6}$. These endogenous ligands and xenobiotics include metal ions, drugs, toxic pollutants, amino acids, etc. The study of interaction between metal ions and proteins is a novel frontier of chemistry and life science and plenty of researches have been carried out about these. The research method include equilibrium dialysis, atomic fluorescent spectrometry, circular dichroism, Raman spectrometry, molecular modeling, etc. ${ }^{7-10}$. Atomic fluorescent spectrometry (AFS) is an effective method to research protein conformation, as we all know that in the protein tryptophan and tyrosine residues show high fluorescence intensity, that is to say the intrinsic fluorescence of protein mainly come from tryptophan and tyrosine residues, so they always function as natural probes to research protein conformation. Fluorescence quenching technique is an important method to research of interactions between several substances and protein, which can help us to know the mechanisms of protein and these substances 5 . In recent years, circular dichroism (CD) developed rapidly and it has been widely used in the research of biological macromolecular structure information. Circular dichroism technology has become a powerful means to obtain the protein secondary and tertiary structure information. Over the past years, many researches had been performed on the binding of metal ions to BSA or $\mathrm{HSA}^{10,11}$. However, using various spectrum means to study the interaction of mercuric chloride with bovine serum albumin (BSA) has scarcely reported.

In the present work, we studied in vitro interaction of mercuric chloride with BSA in the simulative physiological condition by using the fluorescence quenching method, synchronous fluorescence method, UV absorption spectra and $\mathrm{CD}$ techniques. Binding constants, thermodynamic parameters such as entropy change $(\Delta \mathrm{S})$ and enthalpy change $(\Delta \mathrm{H})$ were estimated, the secondary structure changes of BSA with adding the mercuric chloride solution has been investigated, the 
interaction mechanisms of mercuric chloride with BSA and toxicological implications were also discussed.

\section{EXPERIMENTAL}

Bovine serum albumins was purchased from Shanghai Bio Science \& Technology. CD, Ltd. and used without further purification. BSA was directly dissolved in deionized water to prepare the stock solution $\left(2 \times 10^{-5} \mathrm{~mol} \mathrm{~L}^{-1}\right.$, BSA $)$ and kept in the dark at $0-4^{\circ} \mathrm{C}$. Mercuric chloride solution was obtained by dissolving it in deionized water. $0.1 \mathrm{~mol} \mathrm{~L}^{-1}$ tris- $\mathrm{HCl}$ buffer solution of $\mathrm{pH} 7.4,1 \mathrm{~mol} \mathrm{~L}^{-1} \mathrm{NaCl}$ working solution were prepared. All the other chemicals were of analytical reagent grade and distilled or deionized water was used.

Fluorescence measurements: The fluorescence spectra was measured with a $1 \mathrm{~cm}$ path-length cell, the excitation and emission slits were set at $3 \mathrm{~nm}$ each, the excitation wavelength is $280 \mathrm{~nm}$ and the fluorescence spectra were recorded in the range of 220-500 $\mathrm{nm}$.

The fluorescence quenching experiments by $\mathrm{Hg}$ (II) was performed as the following procedures. $1 \mathrm{~mL}$ of $0.1 \mathrm{~mol} \mathrm{~L}^{-1}$ tris buffer ( $\mathrm{pH} 7.4$ ) solution, $1 \mathrm{~mL}$ of $1 \mathrm{~mol} \mathrm{~L}^{-1} \mathrm{NaCl}$ solution, $1 \mathrm{~mL} 2 \times 10^{-5} \mathrm{~mol} \mathrm{~L}^{-1}$ BSA solution and a known volume of $\mathrm{Hg}$ (II) solution were transferred to a $10 \mathrm{~mL}$ test tube, then the mixture was diluted to $10 \mathrm{~mL}$ with water, shaken thoroughly and allowed to stand for $50 \mathrm{~min}$. Fluorescence quenching titration profiles were measured by incrementally adding $\mathrm{Hg}$ (II) solution to the above mixture. Mean while, the fluorescence quenching titration experiment without $\mathrm{Hg}$ (II) were done according to the same procedures. In the meantime, the synchronous fluorescence intensity of the mixture solution was measured at $\lambda_{\mathrm{ex}}=280 \mathrm{~nm}, \Delta \lambda=20 \mathrm{~nm}$ and $\Delta \lambda=60 \mathrm{~nm}$, respectively. Titrations were done manually by using trace syringe. The temperature of samples was kept by recycle water throughout experiments.

UV measurements: The UV experiments were also performed as the following procedures, $1 \mathrm{~mL}$ of $0.1 \mathrm{~mol} \mathrm{~L}^{-1}$ tris buffer ( $\mathrm{pH} 7.4$ ) solution, $1.0 \mathrm{~mL}$ of $1 \mathrm{~mol} \mathrm{~L}^{-1} \mathrm{NaCl}$ solution, $1.0 \mathrm{~mL} 2 \times 10^{-5} \mathrm{~mol} \mathrm{~L}^{-1} \mathrm{BSA}$ solution and a known volume of $\mathrm{Hg}$ (II) solution were transferred to a $10 \mathrm{~mL}$ test tube, then the mixture was diluted to $10 \mathrm{~mL}$ with water, shaken thoroughly and allowed to stand for $50 \mathrm{~min}$. UV measurements were carried out with a model of Cary-100, the path-lengths was $1 \mathrm{~cm}$, Sacnning the wavelength range of 190-400 nm.

CD measurements: CD measurements were carried out with a model $\mathrm{J}-815$, the path-lengths was $0.1 \mathrm{~cm}$. The CD experiments were also performed as the following procedures. $1.0 \mathrm{~mL}$ of $0.1 \mathrm{~mol} \mathrm{~L}^{-1}$ tris buffer $(\mathrm{pH} 7.4)$ solution, $1.0 \mathrm{~mL}$ of $1 \mathrm{~mol} \mathrm{~L}{ }^{-1} \mathrm{NaCl}$ solution, $1.0 \mathrm{~mL} 2 \times 10^{-5} \mathrm{~mol} \mathrm{~L}^{-1} \mathrm{BSA}$ solution and a know volume of $\mathrm{Hg}$ (II) solution were transferred to a $10 \mathrm{~mL}$ test tube, then the mixture was diluted to $10 \mathrm{~mL}$ with water, shaken thoroughly and allowed to stand for $50 \mathrm{~min}$.

\section{RESULTS AND DISCUSSION}

Fluorescence spectra: Mercuric chloride solution has no fluorescent, but it can react with BSA when excited at 280 $\mathrm{nm}$. Fig. 1 showed that the fluorescence spectra of BSA with the increasing amounts of mercuric chloride solution, remarkable decreases of the fluorescence intensity, maximum emission wavelength not migrated.

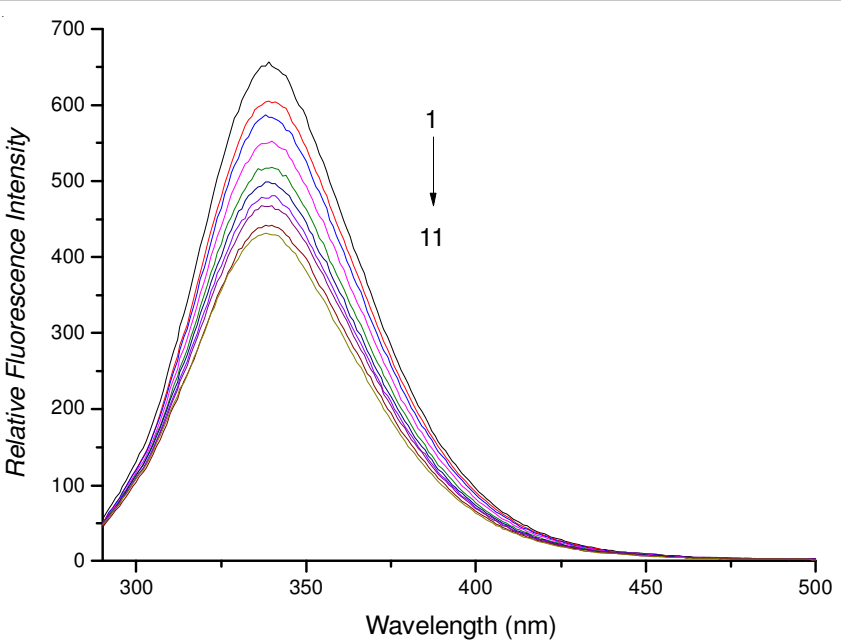

Fig. 1. Effect of $\mathrm{Hg}(\mathrm{II})$ fluorescence spectra of BSA. $\mathrm{C}_{\mathrm{BSA}}=2.0 \times 10^{-5}$ $\mathrm{mol} / \mathrm{L} ; \lambda_{\mathrm{ex}}=280 \mathrm{~nm} ; \mathrm{T}=298 \mathrm{~K} ; \mathrm{pH}=7.40 ; \mathrm{C}_{\mathrm{Hg}(\mathrm{II})}$ from 1 to $11: 0$, $20,40,60,80,100,120,140,160,180,200\left(\times 10^{-5} \mathrm{~mol} / \mathrm{L}\right)$

$\mathrm{Hg}(\mathrm{II})$-induced quenching mechanism of bovine serum albumins: Fluorescence spectroscopy is an appropriate method to study the interactions between small molecule ligands and biomicromolecule. The effects of $\mathrm{Hg}$ (II) on the fluorescence intensity of BSA were shown in Fig. 1. The fluorescence intensity of BSA decreases regularly with increase of concentration of $\mathrm{Hg}(\mathrm{II})$, which called the fluorescence quenching effect.

The quenching of fluorescence is known to occur mainly by collisional process or by ground-state complex formation. The static quenching is due to the formation of ground-state complex between fluorophores and quencher. However, the collisional quenching or dynamic quenching results from the collisions between fluorophores and quencher and the dynamic quenching data were analyzed according to SternVolmer equation.

$$
\mathrm{F}_{0} / \mathrm{F}=1+\mathrm{Kq} \tau_{0}[\mathrm{Q}]=1+\mathrm{K}_{\mathrm{sv}}[\mathrm{Q}]
$$

where $\mathrm{F}_{0}$ and $\mathrm{F}$ are the fluorescence intensity in the absence and presence of the quencher, respectively, $\mathrm{K}_{\mathrm{SV}}$ stands for quenching constant, $\mathrm{Q}$ is the quencher concentration, $\mathrm{K}_{\mathrm{q}}$ is bimolecular quenching constant and $\tau_{0}$ is the life time of fluorophore in the absence of quencher.

According to the Fig. 2, dynamic quenching constants $\mathrm{K}_{\mathrm{SV}}$ were obtained by the slope of regression curves in the linear range, $\mathrm{K}_{\mathrm{q}}$ were calculated based on the fluorescence lifetime of biopolymer about $10^{-8} \mathrm{~s}^{12}$. The results were shown in the Table-1. Genarally speaking, for the dynamic quenching mechanism, quenching rate constants of the fluorescent complexes increase with a rise in temperature and the maximum scatter collision quenching constant of biomacromolecule by all kinds of quenchers is $2.0 \times 10^{10} \mathrm{~L} \mathrm{~mol}^{-1} \mathrm{~s}^{-1}$. On the contrary, for the static quenching mechanism, quenching rate constants of the fluorescent complexes decrease with a rise in temperature. It can be seen from Table 1 that quenching rate constants of BSA decrease with a rise in temperature and it is far greater than the maximum scatter collision quenching constants of biomacromolecule $\left(2.0 \times 10^{10} \mathrm{~L} \mathrm{~mol}^{-1} \mathrm{~s}^{-1}\right)^{13}$. Thus, the fluorescence quenching effects of $\mathrm{Hg}$ (II) is not initiated by the dynamic collision and caused by the static quenching of compounds formation. 


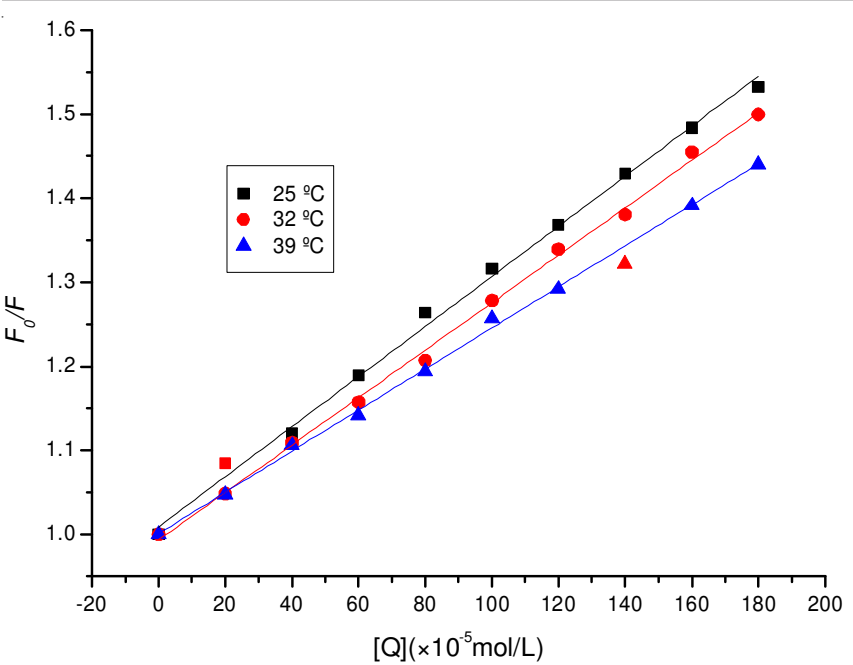

Fig. 2. Stern-Volmer curves of $\mathrm{Hg}(\mathrm{II})$ concentrations versus the fluorescence intensity of BSA in the different temperatures. $\mathrm{C}_{\mathrm{BSA}}=$ $2.0 \times 10^{-5} \mathrm{~mol} \mathrm{~L}^{-1} ; \mathrm{pH}=7.40 ; 25^{\circ} \mathrm{C}$ (filled square); $32{ }^{\circ} \mathrm{C}$ (filled circle); $39^{\circ} \mathrm{C}$ (filled triangle)

\begin{tabular}{ccccc}
\multicolumn{5}{c}{ TABLE-1 } \\
\multicolumn{5}{c}{$\begin{array}{c}\text { QUENCHING RATE CONSTANTS AT } \\
\text { DIFFERENT TEMPERATURES }\end{array}$} \\
\hline Compound & $\mathrm{T} / \mathrm{K}$ & $\mathrm{K}_{\mathrm{sv}} /\left(\mathrm{L} \mathrm{mol}^{-1}\right)$ & $\mathrm{K}_{\mathrm{q}} /\left(\mathrm{L} \mathrm{mol}^{-1} \mathrm{~s}^{-1}\right)$ & $\mathrm{r}$ \\
\hline \multirow{2}{*}{$\begin{array}{c}\text { Mercuric } \\
\text { chloride }\end{array}$} & 298 & 298 & $2.98 \times 10^{10}$ & 0.998 \\
& 305 & 282 & $2.82 \times 10^{10}$ & 0.999 \\
& 312 & 244 & $2.44 \times 10^{10}$ & 0.999 \\
\hline
\end{tabular}

Calculation of association constant $\left(K_{\mathrm{A}}\right)$ and binding capacity (n): Since $\mathrm{Hg}(\mathrm{II})$ induced fluorescence quenching of serum albumins was a static quenching process. Then the static quenching corresponding following Lineweaver -Burk equation ${ }^{14}$.

$$
\frac{\mathrm{F}_{0}}{\mathrm{~F}_{0}-\mathrm{F}}=1+\frac{\mathrm{K}_{\mathrm{D}}}{[\mathrm{Q}]}
$$

where [Q] is concentration of quencher, $\mathrm{K}_{\mathrm{D}}$ is dissociation constant. According to the Lineweaver-Burk equation, the doublereciprocal plots were constructed based on the relationship of $\mathrm{F}_{0} /\left(\mathrm{F}_{0}-\mathrm{F}\right)$ versus various concentrations of $\mathrm{Hg}(\mathrm{II})$ (Fig. 3). The association constants $\left(\mathrm{K}_{\mathrm{A}}=1 / \mathrm{K}_{\mathrm{D}}\right)$ between $\mathrm{Hg}(\mathrm{II})$ and BSA

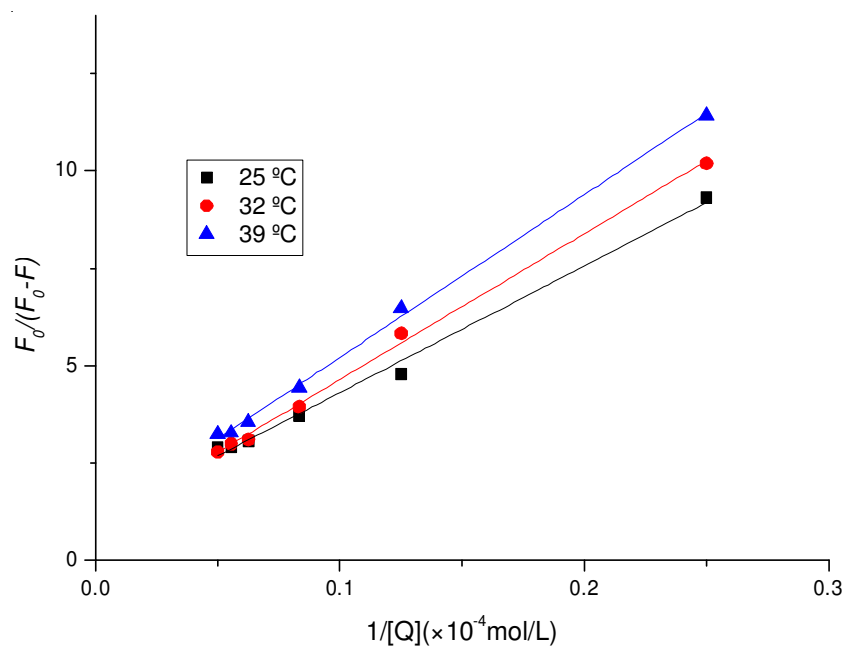

Fig. 3. Lineweaver-Burk double-reciprocal curves of $\mathrm{Hg}(\mathrm{II})$ concentrations versus the fluorescence intensity of BSA in the different temperatures. $\mathrm{C}_{\mathrm{BSA}}=2.0 \times 10^{-5} \mathrm{~mol} \mathrm{~L}^{-1} ; \mathrm{pH}=7.40 ; 25^{\circ} \mathrm{C}$ (filled square); $32{ }^{\circ} \mathrm{C}$ (filled circle); $39^{\circ} \mathrm{C}$ (filled triangle) were obtained from the regression equation of curves (Table-2). From Table- 2 we can see the association constant $\left(\mathrm{K}_{\mathrm{A}}\right)$ values are great, which indicates that $\mathrm{Hg}$ (II) have high affinity to BSA. Further explain that the fluorescence quenching effects of $\mathrm{Hg}(\mathrm{II})$ is caused by the static quenching, not by the dynamic collision.

TABLE-2

BINDING CONSTANTS BETWEEN Hg(II) AND BSA

\begin{tabular}{ccccc}
\hline Compound & $\mathrm{T} / \mathrm{K}$ & $\mathrm{K}_{\mathrm{D}}\left(\mathrm{mol} \mathrm{L}^{-1}\right)$ & $\mathrm{K}_{\mathrm{A}} /\left(\mathrm{L} \mathrm{mol}^{-1}\right)$ & $\mathrm{r}$ \\
\hline \multirow{2}{*}{ Mercuric } & 298 & $32.5 \times 10^{-4}$ & 307 & 0.997 \\
chloride & 305 & $37.4 \times 10^{-4}$ & 267 & 0.998 \\
& 312 & $41.7 \times 10^{-4}$ & 240 & 0.999 \\
\hline
\end{tabular}

The following equation can be used to estimate the number of the binding sites $(\mathrm{n})$ and the binding constant $\left(\mathrm{K}_{\mathrm{A}}\right)$ based on the above conclusions. For the fluorescence quenching is static quenching of compounds formation, it is described as following equation: ${ }^{15}$.

$$
\log \left[\left(\mathrm{F}_{0}-\mathrm{F}\right) / \mathrm{F}\right]=\log \mathrm{K}_{\mathrm{A}}+\mathrm{n} \log [\mathrm{Q}]
$$

where $\mathrm{n}$ is the number of the binding sites, $\mathrm{K}_{\mathrm{A}}$ is the static association constants, $\mathrm{F}_{0}, \mathrm{~F}$ and [Q] represent the same meaning as the above equations, the plots of $\log \left[\left(\mathrm{F}_{0}-\mathrm{F}\right) / \mathrm{F}\right]$ versus $\log [\mathrm{Q}]$ gave a straight line and the slope of such curve was equal to $\mathrm{n}$ (the number of binding sites) while the intercept on Y-axis to $\log \mathrm{K}_{\mathrm{A}}$. The results show that association constants estimated by this method are basically in accordance with these obtained by the above Stern-Volmer equation and LineweaverBurk equation. The number of the binding sites at different temperatures was shown in Table-3. Table-3 shows that the number of the binding sites of $\mathrm{Hg}$ (II) with BSA is 1 , which indicates that a $\mathrm{Hg}(\mathrm{II})$ molecule bound to one BSA molecule.

\begin{tabular}{ccccc}
\multicolumn{5}{c}{ TABLE-3 } \\
\multicolumn{5}{c}{ NUMBER OF THE BINDING SITES AND BINDING } \\
CONSTANTS OF Hg(II) WITH BSA
\end{tabular}

Thermodynamic parameters and acting force: The interaction forces between organic small molecule and large biological molecule may include hydrogen bond, van der Waals force, hydrophobic force, electrostatic force, etc. Because the effect of the temperature is very small, the interaction enthalpy change can be regard to be constant. Therefore, according to the following equations:

$$
\begin{gathered}
\ln \mathrm{K}=\frac{\Delta \mathrm{H}}{\mathrm{RT}}+\frac{\Delta \mathrm{S}}{\mathrm{R}} \\
\Delta \mathrm{G}=-\mathrm{RT} \ln \mathrm{K} \\
\Delta \mathrm{S}=(\Delta \mathrm{H}-\Delta \mathrm{G}) / \mathrm{T}
\end{gathered}
$$

where $\mathrm{T}$ is absolute temperature, $\mathrm{K}$ is association constant at the corresponding temperature and $\mathrm{R}$ is the gas constant. $\Delta \mathrm{H}$, $\Delta \mathrm{S}, \Delta \mathrm{G}$ are change in enthalpy, entropy change, Gibb's free energy, respectively. The values of $\Delta \mathrm{H}, \Delta \mathrm{S}$ and $\Delta \mathrm{G}$ were shown in Table-4. Because when the $\Delta \mathrm{H}<0$, the main acting force is electrostatic force; when $\Delta S>0$, the possible interaction forces are hydrophobic force and electrostatic force ${ }^{16-18}$. Table-4 
showed that the enthalpy change $(\Delta \mathrm{H})$ and free energy $(\Delta \mathrm{G})$ are negative and the entropy change $(\Delta S)$ is positive. The negative free energy $(\Delta \mathrm{G})$ shows that the interaction process is spontaneous and the $\Delta \mathrm{H}<0, \Delta \mathrm{S}>0$ shows that the hydrophobic force and electrostatic force played a major role in the interaction and the structure of BSA is complicated and the acting force between BSA and small molecules usually not single force, but exist several forces at the same time. So besides hydrophobic force there also have other acting force such as electrostatic force, etc.

\begin{tabular}{ccccc}
\multicolumn{5}{c}{ TABLE-4 } \\
\multicolumn{5}{c}{ THERMODYNAMIC PARAMETERS OF THE INTERACTION } \\
BETWEEN Hg(II) AND BSA \\
\hline Compound & $\mathrm{T} / \mathrm{K}$ & $\begin{array}{c}\Delta \mathrm{G} \\
\left(\mathrm{KJ} \mathrm{mol}^{-1}\right)\end{array}$ & $\begin{array}{c}\Delta \mathrm{H} \\
\left(\mathrm{KJ} \mathrm{mol}^{-1}\right)\end{array}$ & $\begin{array}{c}\Delta \mathrm{S} \\
\left(\mathrm{J} \mathrm{mol}^{-1} \mathrm{~K}^{-1}\right)\end{array}$ \\
\hline $\begin{array}{c}\text { Mercuric } \\
\text { chloride }\end{array}$ & 298 & -14.18 & & \\
& 305 & -14.16 & -11.07 & 10.21 \\
\hline
\end{tabular}

Binding sites of the interaction of $\mathrm{Hg}(\mathrm{II})$ with BSA: The intrinsic fluorescence of serum albumin results from the tryptophan and tyrosine residues. In the normal fluorescence, the emission spectra of tryptophan and tyrosine residues are overlap. But the synchronous fluorescence spectra can give some information about the molecular environment in a vicinity of chromophoric molecules. When the wavelength $\operatorname{spacing}(\Delta \lambda)$ of emission and exciation wavelength was fixed at 60 and $20 \mathrm{~nm}$, we would have the synchronous fluorescence information of tryptophan and tyrosine residues, respectively ${ }^{19,20}$. The synchronous fluorescence spectra of $\mathrm{Hg}(\mathrm{II})$ with BSA were shown in Fig. 4. From this figure we can see that the fluorescence quenching effect of tryptophan residues is stronger than the tyrosine residues after $\mathrm{Hg}$ (II) are added. This difference indicates that the binding site of $\mathrm{Hg}(\mathrm{II})$ is nearer to tryptophan than that of the tyrosine residues.

UV absorption spectra: UV absorption measurement is a simple method and applicable to explore the structure and to know the complex formation ${ }^{21-23}$. The UV absorption spectra of the BSA in different ratios of mercuric chloride to BSA under the simulative physiological conditions were measured (Fig. 5). The absorption of BSA(about 210nm) represents the $\alpha$-helix structure of BSA ${ }^{8}$. Fig. 5 showed that the BSA had a

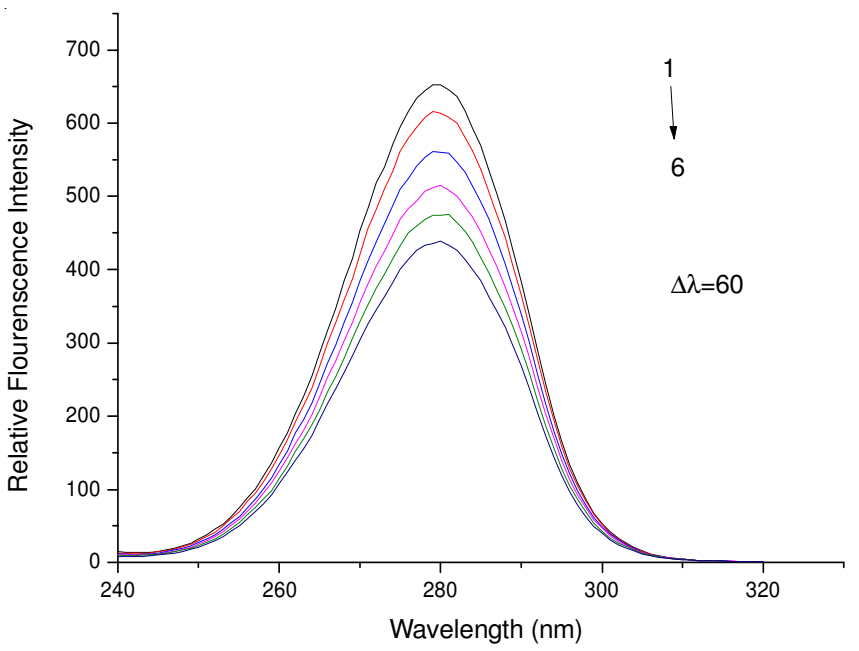

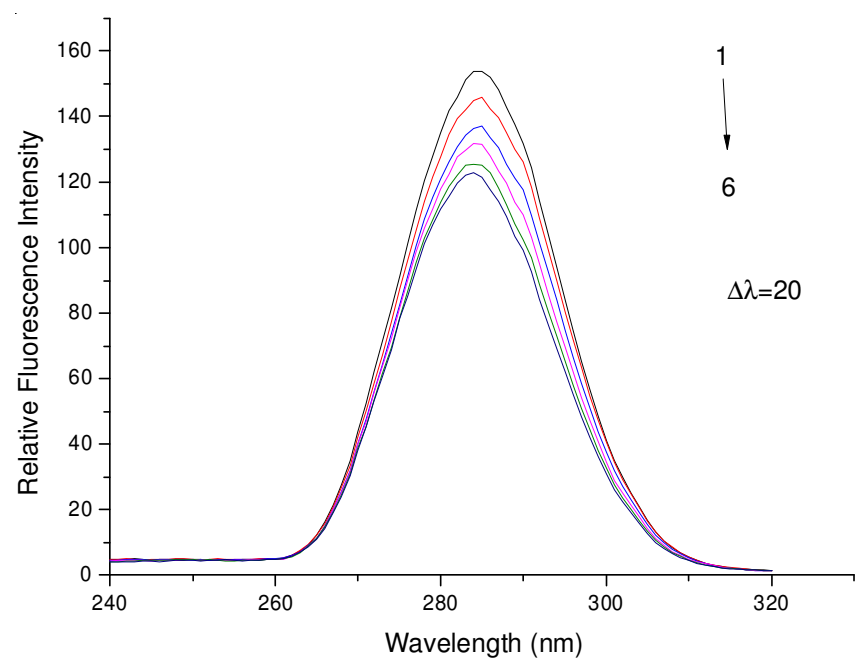

Fig. 4. Effect of $\mathrm{Hg}(\mathrm{II})$ on synchronous fluorescence spectra of BSA. $\mathrm{C}_{\mathrm{BSA}}$ $=2.0 \times 10^{-5} \mathrm{~mol} / \mathrm{L} ; \mathrm{T}=298 \mathrm{~K} ; \mathrm{pH}=7.40 ; \mathrm{C}_{\mathrm{Hg}(\mathrm{II})}$ from 1 to $6: 2,6$, 10,14 and $18\left(\times 10^{-4} \mathrm{~mol} / \mathrm{L}\right)$

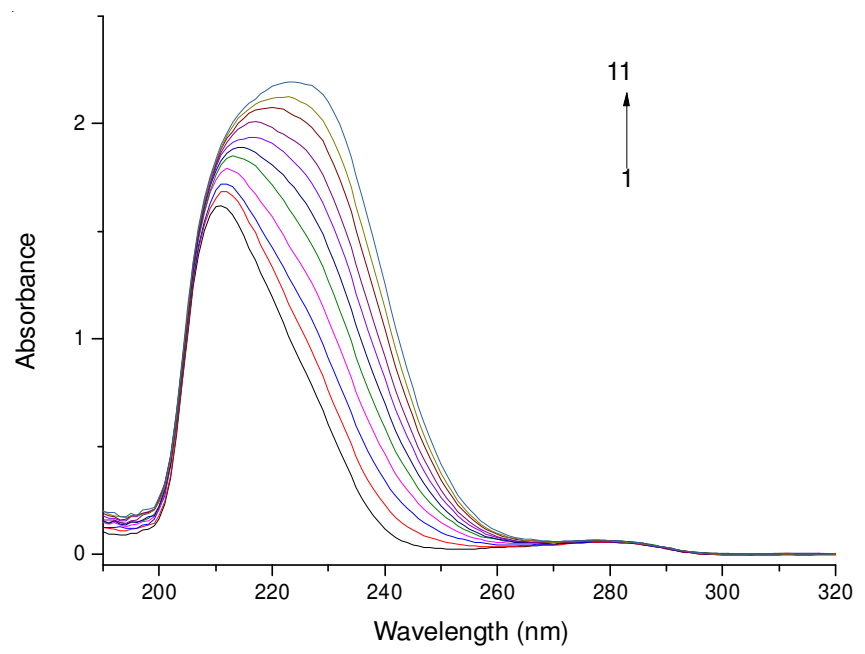

Fig. 5. UV absorption spectra of $\mathrm{Hg}(\mathrm{II})$ with $\mathrm{BSA}$. $\mathrm{C}_{\mathrm{BSA}}=2.0 \times 10^{-5} \mathrm{~mol} /$ $\mathrm{L} ; \mathrm{pH}=7.40 ; \mathrm{CHg}(\mathrm{II})$ from 1 to $11: 0,20,40,60,80,100,120$, $140,160,180,200\left(\times 10^{-5} \mathrm{~mol} / \mathrm{L}\right)$

strong absorption peak at $208 \mathrm{~nm}$ and the peak intensity increased with the addition of mercuric chloride. The formation of the chromophore of mercuric chloride with BSA results in the distinct shift towards a longer wavelength. The above two facts indicate that the interaction of BSA with mercuric chloride took place and this interaction induces the change in $\alpha$-helix structure of the protein.

CD spectra: The changes in the secondary structures of BSA were monitored by CD spectra. It is well known that the magnitude of ellipticity at $208 \mathrm{~nm}$ and $222 \mathrm{~nm}$ can indicative of $\alpha$-helical structure of BSA. Fig. 6 shows the CD spectra of BSA, which exhibits characteristic features of the typical helix structure of the free BSA and its mercuric chloride complex with negative bands at $208 \mathrm{~nm}$ and $220 \mathrm{~nm}$. The binding of mercuric chloride to BSA caused a decrease in band intensity without any significant shift of the peaks. The CD spectroscopic results shown in Fig. 6 and Table-5. The CD results showed that the addition of mercuric chloride to BSA cause a conformational change in the protein, secondary structures calculations based on $\mathrm{CD}$ data suggests that free BSA has a 
high $\alpha$-helix content $51.1 \%$, $\beta$-sheet $0 \%$, turn $28.6 \%$, random $20.3 \%$, addition mercuric chloride, major reduction of $\alpha$-helix was observed from $51.1 \%$ to $47.2 \%$. According to the reports ${ }^{24,25}$, the decrease in $\alpha$-helix structures suggests a partial protein unfolding, that is to say reduced the stability of the protein.

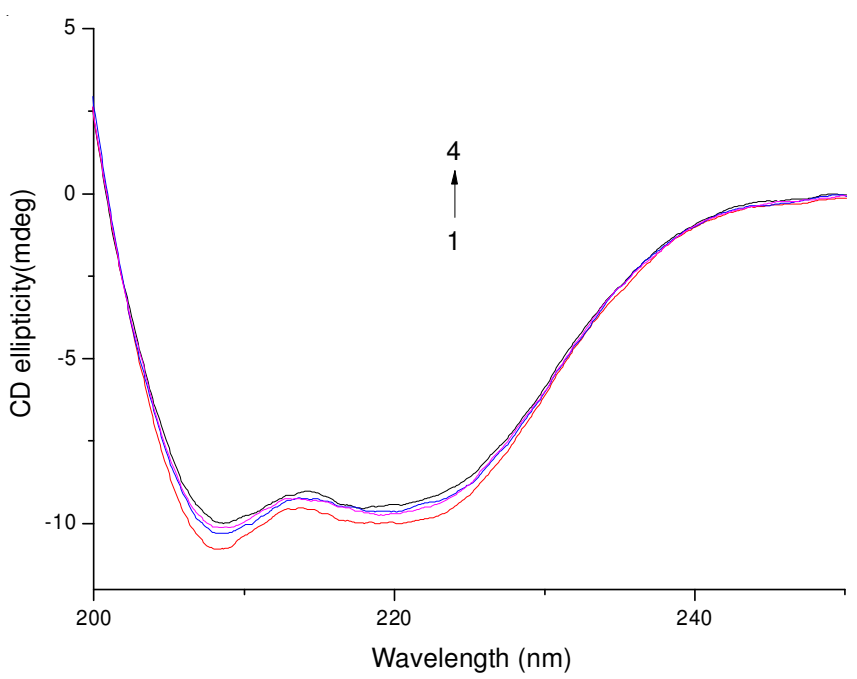

Fig. 6. CD spectra of $\mathrm{Hg}(\mathrm{II})$ with BSA. $\mathrm{C}_{\mathrm{BSA}}=2.0 \times 10^{-5} \mathrm{~mol} / \mathrm{L} ; \mathrm{pH}=7.40$; $\mathrm{C}_{\mathrm{Hg}(\mathrm{II})}$ from 1 to 4 : $0,20,40,60,\left(\times 10^{-5} \mathrm{~mol} / \mathrm{L}\right)$

\begin{tabular}{ccccc}
\multicolumn{5}{c}{ TABLE-5 } \\
SECONDARY STRUCTURE OF BSA COMPLEXES (CD \\
SPECTRA) WITH MERCURIC CHLORIDE AT pH 7.4 \\
CALCULATED BY CDSSTR SOFTWARE \\
\hline & $\alpha$-Helix & $\beta$-Sheet & Turn & Random \\
& $(\%)$ & $(\%)$ & $(\%)$ & $(\%)$ \\
\hline Free BSA $(0.02 \mathrm{mM})$ & 51.1 & 0 & 28.6 & 20.3 \\
$\mathrm{Hg}(\mathrm{II})-\mathrm{BSA}(0.2 \mathrm{mM})$ & 49.5 & 0 & 21.8 & 28.7 \\
$\mathrm{Hg}(\mathrm{II})-\mathrm{BSA}(0.4 \mathrm{mM})$ & 48.0 & 0 & 32.2 & 19.8 \\
$\mathrm{Hg}(\mathrm{II})-\mathrm{BSA}(0.6 \mathrm{mM})$ & 47.2 & 0 & 31.3 & 21.5 \\
\hline
\end{tabular}

\section{Conclusion}

In this work, fluorescence, UV and CD spectra were used to investigate the interaction of $\mathrm{Hg}$ (II) with BSA. The results showed that the fluorescence quenching of $\mathrm{Hg}$ (II) to BSA was static quenching and the binding mode was mainly based on hydrophobic interaction under the simulative physiological conditions. The synchronous fluorescence showed that the binding site of $\mathrm{Hg}(\mathrm{II})$ is nearer to tryptophan than that of the tyrosine residues. The binding properties were further proved by the quantitative analysis data of $\mathrm{CD}$ spectrum. The results of $\mathrm{CD}$ showed that $\mathrm{Hg}(\mathrm{II})$ interaction with $\alpha$-helical of BSA, adding with the mercuric chloride, the percentage of $\alpha$-helical become less and less.

\section{ACKNOWLEDGEMENTS}

The authors are grateful to the Key International Science and Technology Cooperation Project by Science and Technology Department of Zhejiang Province (2007C24012) and the Science and Technology Cooperation Project between the Governments of China and Poland (32-36).

\section{REFERENCES}

1. T.W. Clarkson and L. Magos, Crit. Rev. Toxicol., 36, 609 (2006).

2. L. Magos, T.W. Clarkson and A.R. Hudson, Biochim. Biophys. Acta, 991, 85 (1989).

3. K.M. Pollard and P. Hultman, Metal. Ions Biol. Syst., 34, 421 (1997).

4. I. Onyido, A.R. Norris and E. Buncel, Chem. Rev., 104, 5911 (2004).

5. G.H. Xiang, S.L. Tong and H.Z. Liu, J. Fluoresc., 17, 512 (2007).

6. D. Silva, C.M. Cortez, J. Cunha-Bastos and S.R.W. Louro, Toxicol. Lett., 147, 53 (2004).

7. P. Sen, S. Fatima, B. Ahmad and R.H. Khan, Spectrochim. Acta A, 74, 94 (2009).

8. Q. Wang, Y.H. Zhang, H.J. Sun, H.L. Chen and X.G. Chen, J. Luminescence, 131, 206 (2011).

9. P. Bourassa, S. Dubeau, G.M. Maharvi, A.H. Fauq, T.J. Thomas and H.A. Tajmir-Riahi, Biochimie, 93, 1089 (2011).

10. B. Sudhamalla, M. Gokara, N. Ahalawat, D.G. Amooru and R. Subramanyam, J. Phys. Chem. B, 114, 9054 (2010).

11. A. Nozaki, M. Hori, T. Kimura, H. Ito and T. Hatano, Chem. Pharm. Bull, 57, 224 (2009).

12. J.R. Lakowicz and G. Weber, Biochemistry, 12, 4161 (1973).

13. W.R. Ware, J. Phys. Chem., 66, 455 (1962).

14. M.M. Yang, P. Yang, L.W. Zhang, et al., Chinese Sci. Bull., 39, 31 (1994).

15. R.W. Congdon, G.W. Muth and A.G. Splittgerber, Anal Biochem., 213, 407 (1993).

16. P.D. Ross and S. Subramanian, Biochemistry, 20, 3096 (1981).

17. J. Oravcova, B. Bohs and W. Lindner, J. Chromatogr. B, 677, 1 (1996).

18. M.H. Rahman, T. Maruyama, T. Okada, K. Yamasaki and M. Otagiri, Biochem. Pharmacol., 46, 1721 (1993).

19. C.Q. Ma, K.A. Li, F.L. Zhao, et al., Acta Chim Sinica, 57, 389 (1999).

20. S. Rubio, A. Gomez-Hens and M. Valcarcel, Talanta, 33, 633 (1986).

21. F. Cui, Q.Z. Zhang, Y.H. Yan, X.J. Yao, G.R. Qu and Y. Lu, Carbohyd. Polym., 73, 464 (2008).

22. Y.H. Hu, Y. Liu, J.B. Wang, X.-H. Xiao and S.-S. Qu, J. Pharm. Biomed. Anal., 36, 915 (2004).

23. P.B. Kandagal, S. Ashoka, J. Seetharamappa, V. Vani and S.M.T. Shaikh, J. Photochem. Photobiol. A, 179, 161 (2006).

24. R. Beauchemin, C.N. Nsoukpoe-Kossi, T.J. Thomas, T. Thomas, R. Carpentier and H.A. Tajmir-Riahi, Biomacromolecules, 8, 3177 (2007).

25. E. Froehlich, J.S. Mandeville, J. Jennings, R. Sedaghat-Herati and H.A. Tajmir-Riahi, J. Phys. Chem. B, 113, 6986 (2009). 